\section{OPEN ACCESS}

Volume: 7

Issue: 4

Month: April

Year: 2020

P-ISSN: 2321-4643

E-ISSN: 2581-9402

Received: 06.01.2020

Accepted: 15.02.2020

Published: 01.04.2020

Citation:

Dharmaraj, R. "A Study on

Consumer Behaviour towards Maruti Cars in Vellore

District, Tamilnadu." Shanlax

International Journal of

Management, vol. 7, no. 4, 2020, pp. 80-85.

DOI:

https://doi.org/10.34293/

management.v7i4.1649

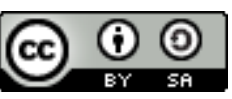

This work is licensed under a Creative Commons Attribution-ShareAlike 4.0 International License.

\title{
A Study on Consumer Behaviour towards Maruti Cars in Vellore District, Tamilnadu
}

\section{R. Dharmaraj}

Head, $P G$ and Research Department of Commerce

Sri Bharathi Women's Arts and Science College, Arni, Tiruvannamalai, Tamil Nadu, India (D) https://orcid.org/0000-0002-0552-9101

\begin{abstract}
The Indian passenger-car industry has been on the continuous growth trajectory in the recent past aided by different contributing factors of national development namely robust economic activity, increased environmental regulations, emerging organized retail industry, government's increased focus on rural development, and development of infrastructure including roads supported by the availability of funds for new projects as well as for easy vehicle financing for prospective buyers. The industry seems to be breaking out of its conventional cyclical trends and of the different size of cars. This study is also going to reveal the various motivating as well as influencing factors for the customers purchasing decision. This research was conducted with the major aim to compare the consumer preference towards passenger cars of Maruti in Vellore district. The convenience sampling technique was adopted with a sample size of 200 respondents. The brands were compared on five attributes, namely color, interior, price, after-sales service and resale value. The buying behavior towards a car of a consumer can be studied by knowing their preference and perceptions about the cars in the market and the possible entrants in the market. This preference and perception sketching will help in knowing what a customer or a potential customer thinks about a given brand of car and what are the possible factors guiding a possible purchase.

Keywords: Consumer Behaviour, Price, Preference, Re sale value, Maruti cars.
\end{abstract}

\section{Consumer Behavior}

Consumer behavior is a complex, dynamic, multidimensional process, and all marketing decisions are based on assumptions about consumer behavior. Consumer behavior can be defined as "the decision-making process and physical activity involved in acquiring, evaluating, using and disposing of goods and services."

The Dictionary of Marketing and Advertising defines consumer behavior as observable activities chosen to maximize satisfaction through the attainment of economic goods and services such as choice of retail outlet, preference for particular brands and so on. This definition brings out that it is not just the buying of a car that receives attention in consumer behavior, but, the process starts much before the car has been acquired or bought.

\section{Review of Literature}

Adele Berndt (2009) discussed in his article that the motor industry plays a critical role in the economy of South Africa, concerning both GDP and employment. Service quality is a fundamental aspect of service provision, and this is especially the case with motor vehicles, where substantial profits are generated in the servicing of vehicles.

Akila, Pamavathy, Balaji and Senthilkumar (2015) examined the brand preference and purchase behavior of B-segment passenger cars in Vellore city. The study was intended to the scrutiny of the customer's brand preference among B-segment cars and their buying behavior with special reference to Vellore City. 
M. Akhila and Ali Ashar Thayyullathil (2015) Customer opinion on cars in Maruti Suzuki, their awareness about various brands and models of Maruti cars, their satisfaction and services provided by Maruti Suzuki showroom. The results indicated that Maruti Suzuki cars are the best and fast-moving cars. The demand for cars by a customer shows an increasing trend at the same time they expected easy handling, safety and security and higher performance, etc. which forces the brands to look for the more innovative model.

Amita Giridhar, Suman Ghalawat and Kavitha C. (2015) The major factors that affect consumer perception towards different brands of the car can be varied and secondly to develop a model framework for various decision areas of consumers while purchasing cars imperative. The result of factor analysis revealed five factors named product strategies, technology know-how, and level of satisfaction, workshop features and lastly service orientation. Factor analysis discloses that consumers were more influenced by product strategies, technology, knowhow and level of satisfaction.

Ching et al. (2008), the relationships between brand equity, brand preference, and purchase intentions on international air passengerse decisions in Taiwan. The findings indicate positive relationships between brand equity, brand preference, and purchase intentions with a moderation effect of switching cost affecting the relationship between brand equity and purchase intentions.

Cristina OPREA (2010) stated in his study that according to a recent study by GFK Romania, the institute number one of market research in Romania, $55 \%$ of Romanians that plan to buy a car, would buy a second-hand car.

\section{Research Gap}

The recent boom in car sales has, to a little bit, been dragged by liberalized financing options and also largely due to the enhanced income levels of the middle-class people. The car industry in India has been on steroids. The domestic sales have reached a level of 2 million units per annum, growing in double digits. It is expected to rise further to 5.2 million units by 2019-20. The overall car industry performance has shown encouraging results for all the segments of the industry. Today, India has become the second-fastest growing car market in the world. Passenger car sales have tripled in six years. The Indian car industry would serve as a key input for the business decisions and segmentation of the Indian market for future demand. From a survey of the literature, it is observed that while all branded car industries are struggling to increase their sales volume in the race of marketing, the consumers of the car are also struggling to buy a car because of hovering thinking due to various dimensional factors. The survey also revealed that research gaps exist in consumer preference and perception of branded cars in general, and with the consistency of preference, factors influencing the preference and brand images in the view of consumers in particular.

It is observed that a large number of research studies have been conducted on consumers' behavior towards various brands of the car concerning different geographical locations in India and abroad. But there are no studies yet which have analyzed the consumer preference and perception towards various brands of the car based on the demographic characteristics of the consumer, which will be of use to the car companies, dealers and marketers to know the consumers elaborately so that they can easily handle the consumers. The survey confirmed that such research was not done in Vellore District. Hence this study was intended to analyze the consumer preference and perception towards various brands of the car in the Vellore District.

\section{Need for the Study}

The last decade has seen the Indian industry gaining maturity and confidence. This industry is counted among the larger contributors to India's economic development, witnessed over the last decade. In this regard, India shall learn from global history to steer ahead in the proper direction. In the case of countries like Japan, German, Italy, the United Kingdom and, more recently, Korea, after the Korean War, post-war reconstruction has been strongly influenced by their manufacturing industries and, in particular, their automotive sector over the past fifty years. In India, too, the automotive industry can play an important role in sustaining its current, significant economic advancement. 


\section{Scope of the Study}

- To examine the perception and purchase behavior of the consumer of Maruti cars.

- To their increasing purchasing power, the people of this district have started to buy cars for business or personal use or the prestige and as a status symbol. Vellore district with a population of $34,80,00829$ is a potential for all products and services, because people of various religions, languages, cultural backgrounds, demographic and psycho-graphic characteristics live in this area.

- The study will highlight the emerging trends in the growth of Maruti car marketing and the major problems faced by the manufacturers as well as dealers in the global competitive era with numerous models with high-tech cars.

\section{Objectives of the Study}

The study is based on the following objectives.

- To study the purpose of using the Maruti cars by the user in the Vellore district.

- To study about which media of awareness to influence to buy a Maruti car.

- To analyze the factors that influence the purchase of Maruti cars.

- To examine about influencing of purchasing decisions of Maruti car users in the Vellore district.

- To identify the type of fuel used by the user of Maruti Cars in Vellore District.

- To study the consumer perception towards various brands of cars in the Vellore District.

- To study the problems faced by the consumers of a car in the Vellore District.

\section{Research Methodology}

The validity of any research depends on the systematic method of collecting the data and analyzing the same in a logical and sequential order. In the present study, the extensive use of both primary and secondary data was made.

Sampling Design Both primary and secondary data are used in the study for analysis purposes. For collecting primary data, the field survey technique was employed in the Vellore district. A well-framed questionnaire was also used to collect the primary data. First-hand information about consumer behavior, satisfaction, and benefits accrued by different Maruti car users was collected from 200 sample respondents.

\section{Collection of Data}

Frame Work of Analysis By a mass of data obtained from the research survey, as well as data from secondary sources collected and presented in the present report, descriptive and analytical research, was considered most appropriate for the study. The researcher used closed-ended and openended questions in the questionnaire to collect primary data.

Primary Data To fulfill the objectives set, a sample study was undertaken by using a wellframed questionnaire that was duly filled by the respondents. The respondents were selected with varying backgrounds based on the important aspects of their age, education, occupation, area and so forth, in the rural and urban areas of the Vellore district.

Secondary Data The primary data were supplemented by a spate of secondary sources of data. The secondary data about the study was gathered from the records published by Maruti car manufacturers.

Statistical Tools Used for Analysis The difference in the extent of using the Maruti car between the different types of respondents based on their gender, age, educational status, occupation, family income level, marital status, family size, nature of the family, wealth position, the period of using Maruti car, the purpose of using the Maruti car, type of car using, the model of Maruti car using, kind of fuel car using was studied using:

- Percentages

- Chi-Squared test

\section{Period of Study}

The researcher herself carried out the field work for this study. The survey was conducted during the period from November 2015 to August 2016. The observations made on the consumer preference and perception towards various brands of cars in the Vellore District for a span of three years, i.e., 2013 to 2016. It has helped the 17 researchers to understand consumer preference and perception towards various brands of cars and to draw appropriate findings and 
suggestions. 1.8.10 Research Instrument A structured interview schedule was developed by the researcher.

\section{Limitations of the Study}

The study is subject to the following limitations.

- The study was conducted only in Vellore district. Hence, the results arrived from the study may not be applied to another area in Tamilnadu.

- The study is confined only to nine hundred respondents among the large sample population in nine taluks, which was considered enough for the study by the researcher.

- The study was examined with limited respondents only.

\section{Nature of the Company Ownership}

Maruti Suzuki is a public limited company listed on the Bombay Stock Exchange Limited and National Stock Exchange of India Limited. SMC is the majority shareholder, with a $54.21 \%$ equity stake in the company. The shareholding pattern of the company has been given on page 50 of the Corporate Governance section of the annual report.

\section{Different Models of Maruti Car}

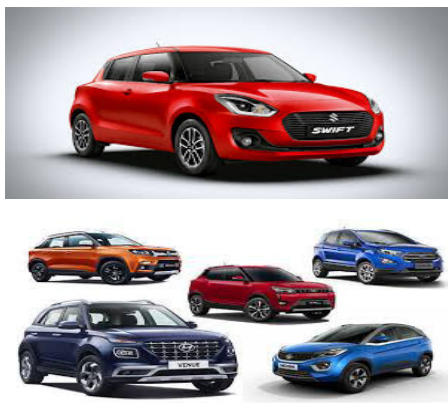

\section{Data Analysis and Interpretation}

The following are the opinion of the sample of Maruthi Cars users concerning the 150 questionnaires. They were tabulated and their opinions were analyzed in this chapter.

Table 1: Gender of the Respondent

\begin{tabular}{|c|l|c|c|}
\hline $\begin{array}{c}\text { S. } \\
\text { No. }\end{array}$ & Attributes & $\begin{array}{c}\text { No. of } \\
\text { Respondents }\end{array}$ & Percentage \\
\hline 1 & Male & 164 & $82 \%$ \\
\hline 2 & Female & 36 & $18 \%$ \\
\hline \multicolumn{2}{|c|}{ Total } & $\mathbf{2 0 0}$ & $\mathbf{1 0 0 \%}$ \\
\hline
\end{tabular}

Source: Primary data
GENDER OF THE RESPONDENT

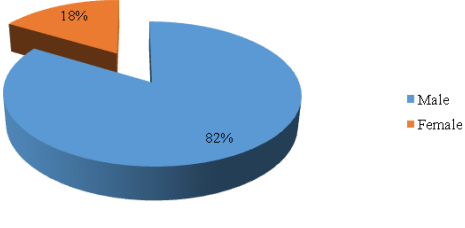

Inference: The above table shows that the male user of the Maturi car is greater than the female user. $82 \%$ of the respondents were male and $18 \%$ of the respondents were female users.

Table 2: Age of the Respondent

\begin{tabular}{|c|l|c|c|}
\hline $\begin{array}{c}\text { S. } \\
\text { No. }\end{array}$ & Attributes & $\begin{array}{c}\text { No. of } \\
\text { Respondents }\end{array}$ & Percentage \\
\hline 1 & Below 25 years & 24 & $12 \%$ \\
\hline 2 & $26-35$ years & 90 & $45 \%$ \\
\hline 3 & $36-50$ years & 56 & $28 \%$ \\
\hline 4 & Above 50 years & 30 & $15 \%$ \\
\hline \multicolumn{2}{|c|}{ Total } & $\mathbf{2 0 0}$ & $\mathbf{1 0 0} \%$ \\
\hline
\end{tabular}

Source: Primary data

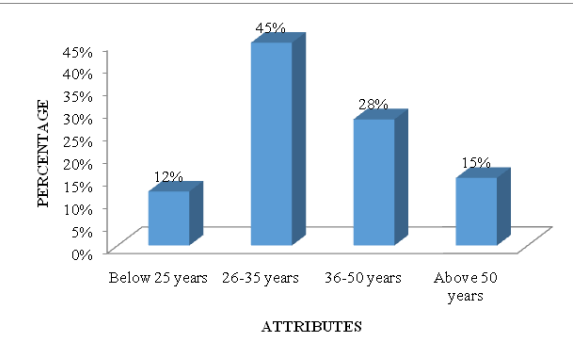

Inference: From the above table shows that the $45 \%$ of the respondents were using in the age group of 26-35years, and $28 \%$ of the respondents were using in the age group of $36-50$ years, and $15 \%$ are in the age of above 50 years and $12 \%$ were using below 25 years.

Table 3: Educational Qualification

\begin{tabular}{|c|l|c|c|}
\hline $\begin{array}{c}\text { S. } \\
\text { No. }\end{array}$ & Attributes & $\begin{array}{c}\text { No. of } \\
\text { Respondents }\end{array}$ & Percentage \\
\hline 1 & Illiterate & 86 & $43 \%$ \\
\hline 2 & School & 34 & $17 \%$ \\
\hline 3 & College & 10 & $5 \%$ \\
\hline 4 & Professional & 70 & $35 \%$ \\
\hline \multicolumn{2}{|c|}{ Total } & $\mathbf{2 0 0}$ & $\mathbf{1 0 0 \%}$ \\
\hline
\end{tabular}

Source: Primary data 


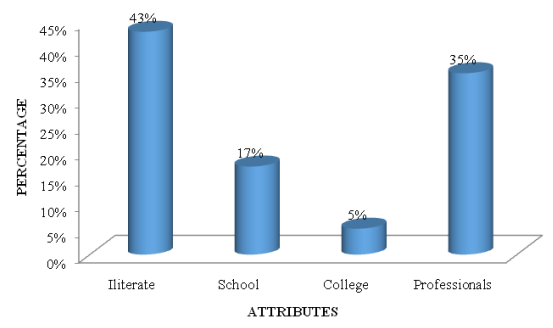

Inference: The above table shows that $43 \%$ of the respondents are illiterate, and $17 \%$ of the respondents are school level of education and $35 \%$ of people are professional and $5 \%$ of the respondents are studied at the college level of education.

\section{Suggestions}

Sometimes, the salesmen are not answering the suitable replay on the queries raised by the buyers about the operation and performance of Maruti cars. Hence, it is suggested that the salesman should be properly trained both in the marketing aspects and in the requisite technical knowledge about Maruti cars.

- The manufacturers should position their products through sales promotional activities such as advertisements etc. Generally, Indian consumers are very strongly influenced by testimonials of sports personalities, endorsements by film stars and celebrities. For positioning the consumer durables like cars, the manufacturers can utilize the endorsement of these celebrities.

- It is also suggested that the car manufacturers should have a separate Research and Development department devoted to 242 marketing and they should conduct periodical surveys about the demand for their cars.

\section{Conclusion}

Consumer behavior mainly depends on human behavior that goes in making purchase decisions an understanding of the consumer behavior enables a marketer to take marketing decision which is compatible with its consumer needs. There are four major classes of consumer behavior determinants and expectations, namely, cultural, socio-economic, personal and psychological. From the discussions made in the previous chapters, there are certain
Maruti car product attributes that are identified in the study as influencing the purchase decision and satisfying the consumers. Maruti Company should concentrate on these features.

The growth in the population of India and the increasing number of middle-class consumers has attracted the attention of car manufacturers and marketers. The Maruti car marketers who study the behavior of consumers should cater to their needs, and then only their business will be a great success.

Realizing the importance of the passenger car industry in the present economic situation, the researcher has analyses the behavior of consumers related to Maruti cars in the Vellore District, Tamilnadu. The researcher also strongly believes that if all the suggestions are carried out by car manufacturers and dealers, they may become the number one brand of car in car marketing.

\section{Scope for Further Research}

The present study has attempted to analyze the consumer buying preference and perception towards various brands of cars in the Vellore District. The findings reported in this study offer several suggestions that there remains a viable prospect for future research. There may be inherent distinctions among the urban, semi-urban, and rural consumers in their buying habits, motives perceptions, etc. due to their different lifestyles. There is a scope for future research to compare the behavior of these three major groups of people. A comparative study may be undertaken between the districts of Tamil Nadu in the consumer buying preference and perception towards various brands of cars. The study dealt with the problems when buying a car in the view of consumers. Future research may conduct on the problems of dealers and manufacturers when marketing the car. Further research can be made on the impact of the brand image of the car on the buying preference of consumers. The researcher presents this study with the hope that this will draw the attention of future researchers and help them in any form for their research. 
References

Akila, M. and Thayyullathi, A. "A Study on Customer Satisfaction towards Maruthi Suzuki in Coimbatore." International Journal of Management and Commerce Innovations, vol. 2, no. 2, 2015, pp. 583-587.

Balasubramani, S., Suganthi, M. and Suresh, P. “An Empirical Study on Consumer Preference towards Hyundai Cars in Salem City." Indian Journal of Research, vol. 2, no. 9, 2013, pp. 20-22.

Gautam Raj Kumar. "Purchase Decision of Indian Consumers: The Factors of Attraction while Purchasing Car." Studies in Business and Economics, vol. 9(3), 2014, pp.29-42.

Gayatri Chopra. "Consumer Preference towards Maruti Suzuki and Hyundai Motors: A Comparative Study of the Automobile Sector." International Journal of Management Studies, vol. 5, no. 3(6), 2018, pp. 84-90.

Girdhar, A., Ghalawat, S. and Kavitha, C. "A Study on Consumer Behavior Considering various Attributes towards Purchasing a Car." International Journal of Science Technology and Management, vol. 4, no. 11, 2015, pp. $175-184$

Gupta, S. "A Study of Buying Decision Influencers for Passenger Car Segment in New Delhi." International Journal of Business and Management Invention, vol. 2, no. 12, 2013, pp. 64-71.

Josephine Stella, A. and Rajeswari, K. "Consumer Behaviour towards Passenger Cars - A Study with Reference to Virudhunagar District of Tamilnadu." IJEMR, vol. 2 , no. 1, 2012.

Kaushik, V.K. and Neeraj Kaushik. "Buying Behavior of Passenger Cars; A Study in South West Haryana." Indian Journal of Marketing, vol. 38, no. 5, 2008.
Madhusmita Choudhury. "An Empirical Study of Car Selection Factors - A Qualitative \& Systematic Review of Literature." International Journal of Management, Technology And Engineering, vol. 8, no. 2, 2018, pp. 3055-3069.

Malhotra, G. et al. "An Empirical Research on Consumer Behavior towards Small Car Segment in Indian market." Business Perspectives and Research, vol. 1, no. 1, 2012, pp. 37-46.

Rai, A.K. "Preference and Purchase Behaviour of Passenger Cars in Jamshedpur City." International Journal of Scientific Engineering and Research, vol. 5, no. 9, 2017, pp. 18-23.

Rajasekar, T. and Rameshkumar, S. "Determinants of Preference towards Passenger Cars - The Case of Madurai City in Tamilnadu." IOSR Journal of Business and Management, vol. 17, no. 7, 2015, pp. 84-88.

Rubha, S. "A Study of Consumer Preference and Perception towards Various Brands of Cars in Tirunelveli District." Manonmaniam Sundaranar University, 2017.

Shende, V. "Analysis of Research in Consumer Behavior of Automobile Passenger Car Customer." International Journal of Scientific and Research Publications, vol. 4, no. 2, 2014, pp. 1-8.

Vishal S. Rana and Lokhande, M.A. "A Study of Consumer Preferences \& Attitude towards Passenger Cars of Maruti Suzuki \& Hyundai Motors in Marathwada Region of Maharashtra." International Journal of Science, Spirituality, Business and Technology, vol. 3, no. 2, 2015, pp. 37-42.

\section{Author Details}

Dr. R. Dharmaraj, Head, PG and Research Department of Commerce, Sri Bharathi Women's Arts and Science College, Arni, Tiruvannamalai,Tamil Nadu, India, EmailID:rd.dharmaraj@gmail.com. 